\title{
Mäns föräldraskap
}

\section{Om faderskap och manlighet i Sverige och England}

\author{
LARS PLANTIN, SVEN-AXEL MÅNSSON \\ \& JEREMY KEARNEY
}

Förväntningarna på mäns föräldraskap har förändrats under de senaste decennierna. Dagens fäder skall inte bara vara aktiva i omsorgen om barnen utan också agera på ett nytt och jämställt sätt på alla områden $i$ hemmet. Hur har dessa kulturella förändringar påverkat mäns föräldraskap och vad innebär det moderna faderskapet för mäns syn på sig själva som män? I artikeln granskas hur fäder från två olika länder, Sverige och England, utformar sitt föräldraskap i ett intimt samspel med olika omgivande strukturer och relationer.

Forskning om mäns föräldraskap är idag ett starkt växande kunskapsfält. Frågeställningarna på området har breddats och berör inte längre enbart hur fäders agerande inverkar på barns utveckling. Nya perspektiv och in-

Lars Plantin är doktorand vid Institutionen för socialt arbete, Göteborgs universitet. Han skriver sin doktorsavhandling om mäns föräldraskap.

Sven-Axel Månsson är professor i socialt arbete och huvudansvarig för det SFR-finansierade forskningsprojektet Fatherhood and Masculinities - a comparative study of ideals and realities of fatherhood formation in Britain and Sweden.

Jeremy Kearney är Head of Applied Social Studies vid Sunderlands universitet. Han är också projektkoordinator för den brittiska delen av Fatherhood and Masculinities. tresseområden har aktualiserats och idag inbegriper forskningen även ett fokus på männen/fäderna själva samt hur faderskapet utformas i vardagslivets praktik och relationer. Parallellt med denna utveckling finns också ett växande forskningsintresse för hur män lever sina liv, skapar sin identitet som män och utformar relationer till omgivningen, till andra män och till kvinnor. Frågor kring dessa saker ställs inom den nya mansforskningen. Dock har mansforskningen hittills i väldigt liten utsträckning uppmärksammat frågor som berör just mäns föräldraskap. Istället har den mest intresserat sig för mäns relation till arbete, sport, 
våld och sexualitet. Dessutom saknas studier inom både mans- och faderskapsforskningen som på ett tydligt sätt knyter samman frågorna kring faderskap och manlig identitet. Ett märkligt fenomen, kan man tycka, eftersom föräldraskapet trots allt upptar en så stor del av många mäns liv och då skärningspunkten mellan dessa både områden öppnar upp för en mängd intressanta frågor av typen: hur upplever män sitt faderskap, hur påverkar förväntningarna på det "moderna" föräldraskapet deras tankar och handlingsmönster och, vidare, hur påverkar dessa erfarenheter mäns syn på sig själva som män?

Avsikten med denna artikel är att diskutera några av dessa frågor. Mer specifikt har artikeln två syften. För det första avser vi att analysera hur olika kulturellt färgade förväntningar inverkar på mäns tankar och handlingar kring föräldraskapet. Detta gör vi utifrån en jämförelse av forskningsmaterial om män och föräldraskap hämtade från två olika länder - Sverige och England. För det andra är syftet att försöka se huruvida mäns agerande i familjelivets vardag håller på att förändras i en mer jämställd riktning. Att i just dessa avseenden göra en jämförelse mellan England och Sverige är intressant mot bakgrund av de stora strukturella och socialpolitiska skillnaderna som finns mellan länderna, inte minst på familjepolitikens område (ESO, 1996). Det komparativa perspektivet har förstås också andra fördelar. Tvärkulturella jämförelser bidrar ofta med nya och oväntade perspektiv. Samtidigt erbjuder de också forskaren möjligheter att inta den utomstående observatörens kritiska position i förhållande till »självklara» företeelser och föreställningar i och om det egna samhället (Hantrais \& Mangen, 1996). Vår artikel baserar sig alltså på en komparativ studie utförd i samarbete mellan Institutionen för socialt arbete vid Göteborgs universitet i Sverige och The School of Humanities and Social Sciences vid University of Sunderland i England. Men mer om studiens uppläggning och genomförande längre fram.

\section{Utgångspunkter och centrala begrepp}

Forskningen kring mäns föräldraskap har under senare åren uppvisat en alltmer mångfacetterad bild av hur män uppfattar och uttrycker sitt föräldraskap. Olikheterna i hur enskilda män framställer faderskapet är ibland mycket större än likheterna och uttrycken tycks variera både över tid och kontext. Därför har faderskapet allt oftare också kommit att betraktas som en social konstruktion, något som formas i samspelet mellan en mängd omgivande relationer och strukturer i männens liv (Coltrane, 1996: Brandth \& Kvande, 1998). Detta gäller såväl relationerna inom familjen, där faderskapet ständigt utmanas och formas i vardagens praktik, som de samhälleliga förväntningar och förutsättningar som kringgärdar föräldraskapet (Backett, 1987; Marsiglio, 1995). Som kommer att framgå av det fortsatta resonemanget, har även vi tagit vår utgångspunkt i detta perspektiv. I analysen har vi lagt stor vikt vid den socio-kulturella kontextens inverkan på faderskapet, men också hur det formas i relationen mellan mannen och kvinnan i vardagslivets praktik. De teoretiska perspektiv som väglett oss i arbetet har bl.a. hämtats från de senaste årens starkt framväxande mansforskning. Här har 
vi särskilt tagit fasta på den teori om kön som utvecklats av den australiske sociologen Robert W. Connell i boken Masculinities (1995). Vidare har vi tagit intryck av den könsteoretiska diskussionen om hur socialt kön "görsu eller skapas i det dagliga samspelet mellan män och kvinnor. Wests och Zimermans (1987) begrepp "doing gender" står centralt i analysen. Men vi börjar med Connell.

Connell (1995) har beskrivit skapandet av kön som ett sätt att strukturera sociala handlingar. På så sätt, menar han, kan man betrakta kön både som "a product and producer of history" (op.cit., s.81). Relationerna mellan könen konstrueras och förändras alltså över tid och formas i interaktion både med de samhälleliga strukturerna och de vardagliga relationerna mellan män och kvinnor. Enligt Connell bör analysen av könsrelationer baseras på en teoretisk modell som omfattar relationer på tre olika områden: makt, produktion och känslor (Connell använder här begreppet cathexis som närmast betyder känslomässig anknytning). I denna artikel kommer vi att på olika sätt beröra alla dessa områden. Vi kommer också att undersöka om det moderna faderskapet innebär en förändrad och mer jämställd relation mellan män och kvinnor eller om det vi ser endast är ett nytt, mer subtilt uttryck för den traditionella »hegemoniska maskuliniteten $\aleph^{1}$, vilket framförts av vissa forskare (Brandth \& Kvande, 1998; Dryden,

1 I Connells (1995) forskning är "hegemonisk maskulinitet" ett centralt och ofta återkommande teoretiskt begrepp. Uttrycket åsyftar dock inte bara mäns dominans över kvinnor, utan innefattar också hur vissa maskulina for-
1999). Redan nu kan vi förutskicka att detta knappast är fråga om ett wantingen-eller" förhållande. Connell menar att det endast är en liten minoritet av alla män som totalt förkroppsligar den hegemoniska positionen. De flesta män befinner sig inte i en sådan nära relation till makten, utan har ett komplext och problematiskt förhållande till den hegemoniska postitionen. Han beskriver denna komplexitet bl.a. med begreppet "complicity", som i direkt översättning betyder medlöperi. Med detta menar Connell att de flesta män lever i ett slags tyst samförstånd med den patriarkaliska makten. Medlöperi innebär helt enkelt att spela med i ett system som gynnar en själv på någon annans bekostnad. Connell talar t.ex. om att män tenderar att tillgodogöra sig "den patriarkaliska återbäringen" (eng. the patriarchal dividend), dvs. de olika fördelar ekonomiska och andra - som män i allmänhet har av att leva i ett mansdominerat samhälle. I det offentliga livet inträffar det förvisso ganska sällan att män öppet tar avstånd från kvinnors krav på ökad jämlikhet. $\AA$ andra sidan är det ganska få som aktivt stödjer eller tar del i en pro-feministisk politik. Om man byter nivå från politik till vardagsliv och betraktar hur män förhåller sig till den hegemoniska maskuliniteten i vardagliga relationer, framträder en ganska komplex bild. De flesta män i vårt samhälle lever ett liv bestående av ständiga kompromisser och förhandlingar med de kvinnor och barn som de delar sina liv med. En in-

mer och uttryck, ges en dominerande position även mellan män. Ett exempel på detta är den heterosexuella manlighetens hegemoni över den homosexuella manligheten. 
tressant tanke i vårt arbete har varit att försöka se om män från olika sociala och kulturella miljöer befinner sig i olika positioner på ett kontinuum mellan manlig maktutövning och demokratisk delaktighet i familjelivet.

För att undersöka detta har vi bl.a. tagit stöd i Wests och Zimmermans (1987) teoretiska diskussion om hur kön "görs". Deras begrepp »doing gender» innebär att kön betraktas som »an accomplishment, an achieved property of situated conduct (in which attention is focused on) interactional and ultimately institutional areas» (op.cit., s. 126). West och Zimmerman hänvisar i sin studie till Berk (1985) som funnit att i de flesta familjer ser man väldigt små variationer i den faktiska fördelningen av arbetsuppgifter eller när det gäller inställningen till denna fördelning. Kvinnor, även när de arbetar utanför hemmet, står för merparten av hushållsarbetet och omsorgen om barnen. Dessutom, menar Berk, tenderar både män och kvinnor att uppfatta detta som ett rättvis modell ("fair» arrangement). Berk menar att det är svårt att förstå hur kvinnor och män gemensamt och på rationell väg kommer fram till en sådan (ojämlik) modell enbart för att klara av hushållsgöromålen. Ännu svårare är det att förstå hur detta kan uppfattas som rättvist. Hon menar att arrangemanget i realiteten understöder två "produktionsprocesser»: produktionen av varor och tjänster i hushållet samt produktionen och reproduktionen av kön. West och Zimmerman hänvisar till ett citat ur Berks egen text där hon skriver:

Simultaneousley, (family) members »do» gender as they "do" housework and childcare, and what (has) been called the division of labour provides for the joint production of household labour and gender; it is the mechanism by which both the material and symbolic products of the household are realised (op.cit., 144).

Det är inte bara så att hushållsarbete främst uppfattas som »kvinnoarbete». Det faktum att kvinnor gör det (oftast och mest) och inte män blir dessutom ett symboliskt uttryck för de "naturliga» skillnaderna mellan könen, menar Berk. "What is produced and reproduced is not merely the activity and artiefact of domestic life, but the material embodiment of wifely and husbandly roles..." (op.cit., s. 14).

En annan forskare som också använt begreppet "doing gender« är Scott Coltrane (1996). Coltrane tar fasta på betydelsen av det aktiva deltagandet i hushållsgöromålen som ett sätt att inte bara åstadkomma en verkligt rättvis fördelning av arbetet utan också att skapa kön på ett nytt sätt. I sina studier av par som själva betecknar sig som jämställda fann han bl.a. att männens aktiva deltagande i omvårdnaden av barnen och i hushållsgöromålen på olika sätt åstadkom förändringar hos männen: "... through the interaction with their children, parents constructed images of fathers as sensitive and nurturing caregivers. The couples were doing gender through direct and indirect childcare.... When domestic activities are shared equally, maternal thinking develops in fathers, as well as mothers, and the social meaning of gender begins to change (op.cit., s. 83). Han hänvisar till Hochschild (1989) och konstaterar att själva sättet att tänka kring kön har stor betydelse för arbetsfördelningen: "Who makes the bed, 
feeds the dog, washes the car, or stays home with the sick child depends on who ought to do those tasks in a particular household" (op.cit., s. 52). Vidare menar han att ansvarsfördelningen i hemmet är en kontinuerlig process av förhandlingar som inte endast baserar sig på ekonomiskt rationella faktorer eller obalans i maktfördelningen, utan också på vad Hochschild kallar, "the economy of gratitude", alltså en slags tacksamhetens ekonomi, ett begrepp som även inkluderar relationsmässiga och emotionella aspekter såsom känslor av skuld, förpliktelse eller uppskattning kopplad till vissa göromål i hushållet.

I vår egen analys har dessa begrepp och resonemang visat sig både relevanta och användbara. Vi har t.ex. tydligt kunnat se hur män från olika samhällsskikt är väl medvetna om de nya förväntningarna på den "moderne fadern", hur paren på olika sätt är ständigt inbegripna $i$ en process av »doing gender" och hur "the economy of gratitude" genomsyrar de intervjuades sätt att strukturera sitt vardagsliv. Men låt oss inte gå händelserna i förväg.

\section{Metod \\ - studiens uppläggning och genomförande}

Som framgått bygger resonemangen i denna artikel på resultaten från ett komparativt forskningsprojekt mellan Sverige och England. En viktig aspekt av projektet har varit att förstå parrelationens betydelse för mäns konstruktion av faderskapet. Därför valde vi att inte enbart göra intervjuer med män utan även med deras partners. Intervjuerna med kvinnorna har i huvudsak inriktats på deras upplevelser av männens föräldraskap och hur de tror att faderskapet inverkat på männens syn på sig själva som män. På så sätt utgör kvinnornas röster ett viktigt bakgrundsraster till männens berättelser. Männen och kvinnorna har intervjuats separat och intervjuaren har alltid varit av samma kön som den intervjuade. Syftet med detta förfaringssätt har varit att underlätta samtalen som ibland berört intima och känsliga samtalsområden. Intervjuerna har utförts hemma hos varje intervjuperson och spelats in på band. Vi har använt en intervjuguide med i huvudsak tre frågekomplex. Dessa har berört:

\section{Upplevelserna av den egna uppväxten.}

Här har vi undersökt hur olika livserfarenheter påverkat utformningen av det egna föräldraskapet. Detta inbegriper såäl relationen till de egna föräldrarna som relationen till olika vänner eller partners.

\section{Faderskap och familieliv}

På detta område har vi tittat närmare på hur faderskapet tar sig praktiska uttryck i familjelivets vardag. Hur ser vardagen ut i barnfamiljerna och hur fördelas de gemensamma sysslorna mellan föräldrarna? Hur avväger man balansgången mellan arbetsliv och familjeliv och i vilken utsträckning använder man sig av socialförsäkringssystemet? Vi har också frågat om hur paren upplever att föräldraskapet har påverkat kärleksrelationen samt hur det sociala livet påverkats av att man bildat familj.

\section{Erfarenheterna av det egna faderskapet:}

Hur ser männen på sina erfarenheter av det egna faderskapet? Vad har dessa erfarenhe- 
ter inneburit för männens självbild? Har upplevelserna förändrats över tid och i så fall hur? Dessutom har vi bett männen beskriva hur de upplever de samhälleliga och kulturella förväntningarna på dagens faderskap. Vilka budskap möter man och hur överensstämmer de med det egna agerandet?

Totalt intervjuades 20 par i England och 30 par i Sverige. I varje land delades paren in i tre lika stora grupper bestående av par med nyfödda barn, par med barn i 5-7 års åldern och par med barn i tonåren. Vår strävan har varit att få en så stor variation som möjligt i materialet vad gäller mäns erfarenheter och upplevelser av faderskapet. Därför har vi försökt att komma i kontakt med män som har olika social bakgrund med avseende på utbildning, yrke, etnicitet ${ }^{2}$, boende och anknytning till arbetsmarknaden. I både Sverige och England har intervjupersonerna huvudsakligen rekryterats via personal vid olika mödravårdscentraler, daghem och skolor, som förmedlat vidare kontakter. I Sverige kontaktades sju par via personer som själva blivit intervjuade (s.k. snöbollsteknik).

Medelåldern hos paren i de båda länderna var ungefär lika. Däremot fanns det stora skillnader i utbildningsnivå. Drygt 55 procent av de svenska männen mot 40 procent av de engelska hade t.ex. eftergymnasial utbildning. Motsvarande siffra för kvinnorna var 57 procent för svenskorna och 25 procent för engelskorna. Även intervjupersonernas socio-ekonomiska bakgrund rymde stora skillnader. Det svenska materialet do-

2 I det engelska materialet saknas det dock personer med invandrarbakgrund. mineras eftertryckligt av personer från medelklassen, medan det engelska materialet domineras av personer från arbetarklassen. Ytterligare en skillnad gäller intervjupersonernas anknytning till arbetsmarknaden. Av de svenska männen var sju procent arbetslösa mot 25 procent av de engelska.

\section{Den socio-kulturella kontextens inverkan på faderskapet}

I båda studierna fann vi att samtliga män var väl medvetna om förväntningarna på den "nye fadern". Däremot framträdde skillnader i vilken utsträckning de engelska och svenska männen hade påverkats av dessa förväntningar.

\section{Svenska förhållanden}

I Sverige har diskursen om det aktiva och jämställda faderskapet en lång historia som stäcker sig över flera decennier. Redan i början av 1970-talet fick den svenska socialpolitiken på det reproduktiva området ett tydligt inslag av jämställdhetssträvanden. Bland annat genomfördes en rad reformer som syftade till att stärka kvinnans position både på arbetsmarknaden och i hemmet. Föräldraförsäkringen gav männen samma möjligheter som kvinnorna att ta ut en lång föräldraledighet samtidigt som ersättningsnivåerna höjdes. Därefter har bestämmelserna kring föräldraledigheten förbättrats till en nivå som givit det svenska socialförsäkringssystemet på detta område en unik status i ett jämförande internationellt perspektiv. I jämförelse med engelska förhållanden erhåller t.ex. de svenska barnfamiljerna ett dubbelt så stort statligt stöd under barnens 
uppväxt (ESO, 1996). Detta har givetvis påverkat både den svenska genuskulturen och föräldraskapets konstruktion (Haas, 1993; Sandqvist, 1987). Följande citat från en av de svenska männen ger en bild av hur djupt förankrat systemet är i en del svenska mäns minnen och erfarenheter. Mannen skulle kunna sägas tillhöra den andra generationens svenska föräldrar med rötter i den svenska familjepolitikens diskurs och generösa försäkringsbestämmelser:

Jag minns min far som mycket aktiv i familjen och jag kan inte se några avgörande skillnader mellan honom och min mor i det avseendet. De arbetade båda heltid men min mor arbetade mycket på kvällar och nätter. Så man kan säga att de överlappade varandra där hemma. När hon jobbade på kvällar och helger fick han ta över allt ansvar där hemma. Han tog hand om oss barn och städade huset och jag minns att han älskade att laga god mat. Jag tror inte det var något unikt för just honom utan så var det nog redan på den tiden. Var inte början av 1970-talet en brytningstid då män började agera mer civiliserat? (Patrik, 31 år)

Ett tydligt mönster som utkristalliserar sig hos de svenska intervjupersonerna är att deras berättelser stämmer väl med den dominerande diskursen och de officiella förväntningarna på det nya faderskapet. Avvikelserna är få och detta alldeles oavsett hur männen agerar i vardagslivets praktik. En överväldigande majoritet av männen uttrycker t.ex. att de som fäder vill vara öppna, engagerade och lyhörda för barnens behov samtidigt som de också vill stå för "ramarna» och vara rättvisa. Denna blandning av både "hårt och mjukt" eller "flexibelt men bestämt", som de själv uttrycker det, går helt i linje med beskrivningar av hur de uppfattar förväntningarna på dagens faderskap. I detta avseende fanns heller inga skillnader mellan männen vad gäller klasstillhörighet. Dock måste vi avstå från alltför bestämda slutsatser på denna punkt, eftersom det svenska materialet domineras av medelklassmän. Med fler män från arbetarklassen hade kanske bilden sett annorlunda ut.

\section{Brittiska förhållanden}

I England, har den socialpolitiska och ekonomiska kontexten under de senaste trettio åren varken uppmuntrat en ökad jämställdhet eller underlättat för föräldrar att kombinera arbete och familjeliv. Först under hösten 1999 har det införts ett system för föräldraledighet som är öppet både för kvinnor och män. Till skillnad från det svenska systemet innebär reformen dock att ledigheten är obetald och begränsad till tre månader för barn under fem år. Trots detta visade det sig att även de engelska männen vara väl förtrogna med förväntningarna på det moderna faderskapet. Denna diskurs, som av de flesta intervjupersonerna betecknades som något nytt och specifikt för dagens generation, tycktes utöva ett visst tryck på hur fäderna borde agera. En av männen säger t.ex.:

I do feel guilty at times going to work. I feel guilty if I am lying in bed in the middle of the night and my partner gets up to feed the baby, even if it's not my turn to do it....but I feel as though you have got to be there as a a team, it's not a one man or one person show, you've got to try and share chores and help each other. I think men should have equal responsibilities to what women have when it comes to bringing children up. So whether the man is becoming softer I don't know, or wheather it's a sign of the times. For example 
on a Saturday you can go into Sainsburys and its surprising how many men are shopping. Ten years ago that would never have been the case. (Jeff, 36 år)

En annan säger:

If you think of fifty years ago, less than that, ironing, washing, cooking was for the woman, the car was for the man. Society is a lot different now but I think there is still that tendency. I think any man who wants to care for his wife or the family or the house, still gets very involved. I don't belive that the two are overlapped yet. In a sense if you have two circles, there is a strong overlap between the two. (Tom, 30 år)

I jämförelse med de svenska männens berättelser gav dock de engelska intervjuerna tydliga signaler om att den nya faderskapsdiskursen i England inte till fullo accepterats på en social och kulturell nivå. Framför allt de engelska arbetarklassmännens berättelser vittnade om många problem med att försöka skapa en ny, konstruktiv fadersidentitet då försöken ofta motarbetades genom direkta utmaningar från omgivningen. En av männen beskriver t.ex. hur han blivit utsatt för hånfulla kommentarer av sina arbetskamrater då han förkortat sin arbetstid efter sitt barns födelse:

...because over the last three or four weeks I've started not doing the overtime, I'm getting called a "soft tart" (på svenska ungefär: toffel), you know, "are you a man or a mouse?" or "tell your wife what to do". There's a bit of macho in something like that. (John, 30 år)

En annan man beskriver hur han mött ett liknande motstånd från sin egen far:
My dad will sometimes say "where is he today, has he got his pinny (på svenska: förkläde) on in the kitchen?" and I was thinking I'm like my uncle, because he's always been helpful around the house and my dad used to say "Oh, he's a bloody poof ( $p a$ svenska: bög) him, man". (Tim, 33 år))

I denna kluvna situation, i vilken männen är väl medvetna om hur de borde agera i faderskapet men samtidigt motarbetas i sina försök till förändring, skapas stora svårigheter att på ett individuellt plan sammanlänka den moderna faderskapsdiskursen med den manliga självbilden. Flera av de engelska männen gav t.ex. uttryck för en relativt traditionell ideologisk syn på könsrelationerna, samtidigt som de uppvisade ett mycket aktivt engagemang i hemmet och barnen. Andra män beskrev en stolthet över föräldraskapet, samtidigt som de ibland upplevde tvivel när faderskapets praktik kolliderade med den manliga självbilden:

\footnotetext{
You are proud of it if you have your son with you, you should be proud. Your child is your blood and it doesn't come into an equation of feeling soft or not.//The only time I would have any sense of that would be at the nursery school..it's all women. I might feel it a bit offputting because it's all women in there with their children. Otherwise, on the beach or in the shops, at football, not at all. (Sid, 27 år)
}

I Sverige däremot, tycktes den djupare samhälleliga förankringen av faderskapsdiskursen underlätta för männen att integrera det moderna faderskapet med synen på sig själv som man:

För mig är det fullständigt naturligt att vi delar på allt arbete här i hemmet. Det är liksom inget konstigt med det. Jag menar är man för- 
älder och lever i en familj så går det ju inte att välja bort en massa saker som måste göras här hemma. Vi jobbar ju heltid båda två så vi har ju lika lite tid.....eller jag menar vi stressar lika mycket för att försöka hinna med allt, du vet, kring ungarna och så. Kvällarna är ju rena cirkusen numera då man skall fixa mat, tvätta, hjälpa barnen med läxorna, gå på föräldramöten, lägga de små barnen osv. Det gäller ju att få till det så det fungerar och då kan man inte säga »det gör inte jag för det känns inte manligt« eller så. Så var det kanske förr i tiden men definitivt inte nu, det funkar inte. Ibland är ju min fru borta på kurs eller är och tränar på kvällarna, då tar jag allt själv och detsamma gäller för henne när jag är borta. Man får ju hjälpas åt att försöka klara det hela tillsammans. Blir det ändå så att man inte hinner med, som det kan vara i vissa perioder, då får man säga till på jobbet att man måste sticka lite tidigare. Det är ju inte konstigare än så. (Gustav, 42 år)

Jämförelsen mellan de båda materialen visar alltså att i England har den traditionella manligheten börjat utmanas av en ökad familjeorientering hos den nya generationen fäder. Samtidigt har de nya förväntningarna på faderskapet inte lyckats etablera sig på ett lika starkt sätt som i Sverige. Männens agerande har dock mer och mer kommit att hamna i den engelska samhällsdebattens fokus, vilket försvårar för dagens män att agera som sina egna fäder. Detta trots att forskningsresultat visar att männen fortfarande drar stora fördelar av det patriarkala samhällssystemet (Connell, 1995; SOU, 1998). Samtidigt är det rimligt att påstå att värdet av dessa fördelar ter sig oklara eller är ibland nästan obefintliga för vissa grupper av män. De engelska arbetarklassmännen kan t.ex. inte sägas har gjort några direkta vinster på arbetsmarknaden de senaste decennierna.
Den ekonomiska utvecklingen har länge varit mycket dålig för denna grupp, som lever under förhållandevis osäkra inkomstförhållanden och ofta drabbas av arbetslöshet. I ljuset av denna utveckling, tonar också fram en bild som visar hur de engelska männens svårigheter med att integrera det nya faderskapet med den egna manliga självbilden bottnar i sociala klasskillnader. Granskar man t.ex. de brittiska medelklassmännens tankar och handlingar i faderskapet finner man stora likheter med de svenska männen. Det gäller inte bara deras sätt att uttrycka sig, utan faktiskt också deras förändrade beteende i familjelivet. Flera av dessa män, som har hög utbildning och välbetalda yrken, har också uttryckt en medvetenhet om att deras egen syn på faderskapet inte är representativ för alla engelska män och att den kanske inte har full legitimitet på alla nivåer i samhället. En av männen kommenterar synen på det nya faderskapet med att säga: »Without getting into class issues, certainly with the people I mix with, it is the norm». Arbetarklassens män är alltså de som har störst svårigheter med att väga samman det nya faderskapet och den traditionella synen på manlighet. I följande resonemang från en arbetslös man, som bär på huvudansvaret för hemarbetet under dagarna, tydliggörs denna problematik:

I think it's easier for a woman to cope than a man. It's nature. It's not that I'm being...I think itıs just natural. It's natural instincts for a woman. I think women are born with it...I've always felt strongly about that. It's caused a couple of arguments between me and my partner because I've said "It's natural for a woman". A little lad is born and the first thing they do is play football or play with boys' toys. 
A little girl has an iron, and dolls, nappies on dolls, dolls that cry, and even wet themselves now. I just think that women find it easier to cope with children. I don't know why. No, I'm not biased. I don't say "women should do this". I believe in equal rights and all that. (Sid, 27 år)

Flera av de engelska arbetarklassmännen uppvisar ett ökat engagemang i familjen. Samtidigt är det uppenbart hur de i talet ofta uttrycker en mer eller mindre traditionell syn på könsrelationerna. Det, som de ofta ser fram för sig är, antingen att bibehålla de traditionella äktenskapliga rollerna eller att närma sig ett icke färdigdefinierat alternativ, dvs. att vara en "modern man" i ett mer jämställt förhållande. Det sistnämnda betraktas dock fortfarande med både skepsis och osäkerhet och som något som framför allt tillhör medelklassmännens värld.

Mest överraskande i det engelska materialet var de arbetslösa männens förvånansvärt stora engagemang i hemmet och barnen. Låt vara att skälen till detta förmodligen kan uttryckas i termer av strukturellt tvång. Den långa och ofta definitiva friställningen från arbetsmarknaden har tvingat dem till en omorientering. Detta antyder en mer komplex utveckling i männens agerande än vad tidigare forskning visat. Denna har nämligen hävdat att det lägsta engagemanget i barnen och hushållsarbetet finner man i familjer där mannen är arbetslös och kvinnan arbetar halvtid (Ferri \& Smith, 1996; O’Brien, 1992; Wheelock, 1990). Kanske kan man säga att de förändringar vi här tycker oss se i det engelska materialet är ett uttryck för dynamiken och föränderligheten i relationen mellan könen.

Sammanfattningsvis kan vi konstatera att de motsägelser i ideologi och praktik som vi funnit hos många av de engelska fäderna, inte har visat sig på samma sätt hos de svenska männen. ISverige har diskursen kring det nya faderskapet och jämställdheten en så förhärskande position att få män uttrycker sig i strid med dess riktlinjer. Samtidigt förhåller det sig givetvis inte så att alla de svenska fäderna agerar på ett sätt som överrensstämmer med förväntningarna på det nya faderskapet.

\section{Faderskapet $i$ vardagens praktik}

Precis som männen i de båda länderna hanterar faderskapsdiskursen på olika sätt, framträder också intressanta skillnader i intervjupersonernas berättelser om vardagslivet i familjen, i hushållet och tillsammans med barnen. Som vi tidigare framhållit kan Wests och Zimmermans idé om "doing gender« användas för att förstå hur könsrelationer skapas och upprätthålls i det vardagliga umgänget i familjen. Begreppet är ursprungligen hämtat från Berk (1985), som uppmärksammat rättvisefrågan i parrelationer och som noterat att det ofta är mycket svårt att förstå rationaliteten bakom vissa argument och beslut om ansvarsfördelningen i hemmet. Hennes tanke är att det inte går att begripa hur en ojämlik fördelning av hushållsgöromål kan uppfattas som en rättvis lösning av båda parter, utan att samtidigt förstå den symboliska dimensionen hos denna fördelningsprincip. Enligt Berk är fördelningen i sig en bekräftelse på att förhållandet mellan könen är som »det ska vara». »Doing gender» är ett viktigt begrepp eftersom det för tankarna bort från ett 
snävt materiellt fördelningsperspektiv och skapar utrymme för de symboliska och emotionella innebörderna i parförhållandet. Dock anser vi att Berk alldeles för enkelt avvisar rättvisefrågan, särskilt eftersom våra intervjuer visar att denna har stor betydelse i männens och kvinnornas sätt att tänka och handla. Framför allt gäller det om man i diskussionen också inbegriper de "yttre" finansiella och strukturella förutsättningar som direkt inverkar på familjelivets vardag. Begreppet rättvisa kan dessutom ha olika innebörd för de enskilda paren eller individerna och behöver inte vara liktydigt med att man gör samma saker lika mycket. Bäck-Wiklund \& Bergsten (1997) menar t.ex. att andra värden och dimensioner, så som känslan av ömsesidig tillit, lika värde eller individuell autonomi, kan fylla upplevelsen av jämlikhet eller rättvisa.

I vår studie är det speciellt de svenska paren som betonar vikten av rättvisa och rationalitet, när de talar om strategierna för att organisera vardagslivet. Inte minst framkommer detta på ett tydligt sätt, när de argumenterar för tankarna bakom den ofta traditionella fördelningen av föräldraledigheten. Att kvinnan oftast är den som tar ut den längsta ledigheten förklaras i de flesta fall med att männen både tjänar mer och har flexiblare arbetstider, vilket ger familjen större möjligheter att få mer tid tillsammans:

För oss var det inte så svårt att bestämma vem som skulle vara hemma med Annika. Janne jobbar ju mycket på oregelbundna tider och det gör att han tjänar mycket mer än jag gör. Vi skulle alltså förlora mer ekonomiskt på om han var hemma än om jag tog ledigt. Sen får vi ju alla tre mer tid tillsammans på dagarna ef- tersom han är mycket kompledig eller inte börjar förrän senare på kvällen. Du vet, mitt jobb är ju fast mellan 8.00-16.00 och jag kan aldrig gå ifrån om jag skulle behöva det. Janne har däremot lättare att byta bort vissa arbetspass så att han ibland kan vara ledig länge. Och jag vet inte... men jag hade nog också tyckt det hade känts konstigt att inte vara hemma nu när Annika är så liten. Det första året tror jag är viktigt att mamman och barnet har tillsammans... alltså jag menar inte att jag skulle förbjuda Janne om han tvunget ville vara ledig, men om man tänker på vad som är bäst för alla tre i familjen så tjänar vi klart på att jag är hemma, både ekonomiskt och i gemensam tid tillsammans. (Anette, 28 år)

I England, där mäns möjligheter till ersättning för föräldraledighet inte finns, var det få som ens hade övervägt tanken på att mannen skulle stanna hemma med barnet en längre tid. Kostnaderna skulle bli alltför stora för familjen. Även här var det alltså ekonomiska överväganden som låg bakom männens beslut att fortsätta arbeta. För många av de engelska arbetarklassmännen innebar emellertid de låga inkomsterna att det inte alltid var lika självklart vem som skulle vara hemma med barnet. Snarare avgjordes det av vem som hade störst möjlighet att få eller behålla ett arbete. Men, som vi tidigare nämnt, är ekonomisk rationalitet nästan aldrig det enda som avgör parens fördelningsprinciper. Även de känslomässiga aspekterna har stor inverkan på hur paren organiserar sin vardag. Detta framkommer också tydligt i citatet från Anette, där hon framhåller hur viktigt det är att "mamman och barnet är tillsammans» det första året och att familjen ges så mycket gemensam tid som möjligt. Hochschild (1989) har dragit liknande slutsatser och hävdar att kunska- 
pen om samspelet mellan det praktiska och emotionella är av vital betydelse för att förstå huruvida paret upplever sina fördelningsstrategier som rättvisa eller ej. Det är nämligen på båda dessa områden, säger hon, som parens könsideologi skapas, upprätthålls och omsätts i handling.

Som vi tidigare nämnt stödjer också Coltranes (1996) forskning detta resonemang även om han mer betonar det praktiska agerandets förändringspotential vid konstruktionen av kön. Han fann t.ex. att när män aktivt interagerar med sina barn och delar ansvaret för hemarbetet med kvinnan, skapas en förändring -»a transformatory effect» - hos männen som inverkar både på uppfattningen om faderskapet och den egna könsidentiteten. Vårt material understödjer i detta avseende Coltranes resonemang, då de flesta männen säger sig ha fått en ny syn på sig själva som män genom faderskapet. En del har uttryckt att upplevelsen av förlossningen inneburit vad som närmast kan karaktäriseras som en känslomässig revolution, medan andra talat om en mer långsam, men lika fullt genomgripande, förändringsprocess. Speciellt i det svenska materialet finns talrika beskrivningar av hur dessa förändringar påverkat männens agerande både hemma, på jobbet och $\mathrm{i}$ andra sociala situationer:

Det har ju givetvis inneburit massor för mig att få barn. Det största är nog att man inte längre är så egocentrerad, att man har mognat på något sätt. Jag ser t.ex. på kolleger som inte har barn hur jordaxeln går rakt genom huvudet på dom själva. Allt är centrerat kring det egna. Alltså, även jag kan vara ego-trippad ibland, precis som alla andra, men på något sätt känner jag starkt: att få barn har innebu- rit att man också kan bortse från t.ex. sin yrkesroll ibland. I min bransch är det så lätt att bli ego-trippad och tro att hela livet handlar om det man gjorde på dagen var bra eller dåligt. Det är så prestationsbundet. Många som inte har barn går nog hem och sitter och funderar på jobbet, vad som kan göras bättre och så. Medan för mig spelar liksom jobbet inte så stor roll, från det att jag har öppnat dörren där hemma. För då kommer det två ungar rusande mot mig och skall berätta en massa om vad de har gjort i skolan och så. Jobbet liksom försvinner i det sammanhanget. För dom kollegerna som inte har barn blir yrket kanske ibland hela deras identitet och det tror jag är farligt. Dom blir liksom så traditionella där yrket betyder allt i livet. För mig är jobbet bara en del av min identitet eftersom min privatperson eller privata identitet utgör en så stor annan del. På det sättet tror jag att jag är helare som person, mer harmonisk och har ett bredare känsloregister. Det bästa är ju om de här två delarna kan växelverka med varandra, där familjedelen kan få ta över ibland, när det krävs, och där arbetsidentiteten kan få ta över i perioder när det är mycket jobb på gång. För mig har det t.ex. inneburit att jag kan vara mer kreativ på jobbet eftersom det finns omväxling i mitt liv, eller jag kan säga så här: »jag har nog blivit en bättre och en mer mogen person både på jobbet och hemma sedan vi fick barn". Genom barnen har man ju fått lära sig att ha mer tålamod, bli lite "mjukare» i sin attityd och inte vara så fyrkantig. Det är egenskaper jag har enorm nytta av på jobbet. Dessutom är det så, att om allting kanske har varit skit på jobbet så kan man ju hämta kraft hemma, speciellt i kontakten med barnen. Hemma vet man ju att man alltid blir älskad för den man är, så är det inte på jobbet. Det gör ju att man oftast hellre väljer att sticka hem till familjen än hänga med arbetskompisarna ut om dom skall ta en öl efter jobbet. Det lockar liksom inte på samma sätt längre. (Jonas, 46 år) 
Så här berättar Fredrik om en liknande upplevelse:

Jag känner mig mycket tryggare och har blivit en mycket ödmjukare person sedan vi fått barn. Jag vet inte, men det känns som att jag har förändrats en hel del sedan jag blev pappa. Man lär sig något nytt varje dag av sina barn. Jag tycker jag speciellt ser det på jobbet där jag har blivit mer tolerant, mindre fördömande och att jag har utvecklat ett nytt intresse för mellanmänskliga relationer. För mig som chef har det varit viktigt att utveckla sådana kvalitéer. Jag har t.ex. gått olika kurser om gruppdynamik och team-psykologi. För ett par år sedan hade jag vägrat att gå på något sådant. Och jag har även börjat uppmuntra mina anställda att ta ut föräldraledigt eftersom jag tror att folk utvecklas i kontakten med barn. I slutänden är det något som faktiskt gynnar företaget alltså att ha anställda som känner sig mer mogna. Jag menar det har ju varit så för mig själv, jag känner mig mycket mer tillfreds och lugn nu på jobbet. Jag behöver t.ex. inte längre springa omkring i slips varje dag för att få en social status eller position och jag behöver inte heller spela en massa roller utan istället är jag trygg i mig själv. (Fredrik, 43 år)

De svenska männen tycktes generellt sett ha lättare än de engelska männen att identifiera dessa känslomässiga förändringar. Återigen är förmodligen den mer integrerade faderskapsdiskursen i Sverige en starkt bidragande orsak till detta. De flesta svenska paren hade t.ex. en tydligt uttalad strategi för föräldraskapet som berörde omsorgen av barnet/barnen, vem som skulle ta ut den mesta föräldraledigheten och hur man skulle organisera sin ekonomi. De brittiska männen däremot, beskrev ofta perioden efter barnets födelse som en "kulturchock", eftersom de tyckte sig sakna vägledning för hur det moderna faderskapet skall se ut i praktiken. Få av de brittiska männen gav alltså uttryck för en klar planering och förutbestämda strategier i detta avseende. Undantaget utgjordes av en del medelklassmän, som både hade uttalade strategier och kände sig redo för föräldraskapet.

\section{En komplex bild}

Både Berk (1985) och Coltrane (1996) framhåller det reflexiva förhållandet mellan omsorgen om barnen, deltagandet i hushållsarbetet och synen på kön. Våra resultat styrker denna tanke, att ju mer männen deltar och engagerar sig i arbetet med barn och hushåll, desto mer förändras deras syn på manlighet i allmänhet och på sig själva som män i synnerhet. Samtidigt tyder resultaten på att en starkt pådrivande faktor i denna process är de utbredda och numera etablerade normativa föreställningarna om det nya faderskapet, som legitimerar en sådan utveckling. Men självfallet finns det ingen automatik i detta. Det är välkänt från tidigare forskning att många män »i talet» gärna bekänner sig till den nya faderskapsdiskursen utan att för den skull efterleva dess budskap i praktiken (Segal, 1990; Dryden, 1999). Redan under tidigt 80-tal myntade den svenske mansforskaren Lars Jalmert uttrycket i-princip-inställningen, som innebär just detta att män ofta uttalar sig om hur de bör agera i olika situationer, men att de i realiteten handlar på helt andra sätt. "Speciellt utmärkande är detta vad gäller sådana områden som kan betraktas som jämställdhetsområden"(Jalmert, 1984, s. 76). Har det då inte hänt någonting på alla dessa år? Jo, det har det. Och det beror inte endast på att 
många av våra intervjuade män säger sig tänka och agera som moderna fäder eller på att deras partners faktiskt konfirmerar deras utsagor. Inte heller beror det på, som Dryden (1999) menar, att paren oftast är alltför måna om att visa upp en enig yta för utomstående, i det här fallet forskaren. Snarare beror det på att de män, som formar sina genusrelationer i jämställd riktning, är så många fler än de som säger att de av olika anledningar inte svarar upp mot de nya förväntningarna och ofta också får kritik för detta av partnern. Detta säger vi med reservation för att vår undersökning inte är en statistisk undersökning med generaliseringsanpråk.

I det brittiska materialet var det endast sju par av 20 där mannen inte svarade upp mot kvinnans förväntningar på ansvarstagande i hemmet. Samtliga var väl medvetna om situationen och klargjorde tydligt att de inte agerade som de borde. Anledningen till den sneda ansvarsfördelningen i familjearbetet varierade från par till par, men påfallande ofta tycktes mannen och kvinnan ha stora relationsmässiga problem och flertalet av dem övervägde att skiljas. Samma mönster återfanns bland de svenska paren. Fyra av de åtta paren, i vilka kvinnan uttryckte ett missnöje med fördelningen av arbetet $\mathrm{i}$ hemmet, talade i intervjuerna om eventuell skilsmässa. En av kvinnorna beskriver tydligt hur upplevelsen av ojämlikhet och orättvis fördelning ökat i takt med att parets känslomässiga relation försämrats:

Den här helgen har varit alldeles grym, det blev tal om skilsmässa igen. Jag orkar inte ha det så här längre. Han klagar över att jag har förstört hans liv, att jag har utnyttjat och lurat honom.
Framför allt säger han att jag har förstört hans liv genom att inte vilja ha sex med honom längre. Men jag säger att det är väl inte så konstigt. Det första som lämnar kvinnan när man har ett sådant förhållande som vi har, är den sexuella driften. Det har varit så även förr när vi haft det jobbigt men då har vi alltid kunnat hitta tillbaka till varandra. Men nu har vi haft kronofogden efter oss, huset har varit ute på exekutiv auktion och allt har varit jättejobbigt. Sånt tär ju? Det är så mycket problem jag har fått ta i, så jag får ingen ro till att ha sex. Förmodligen tycker han att jag inte är den kvinnan han gifte sig med, att jag har förändrats. Men det gäller även honom, han har blivit en helt annan person. Även om det alltid varit jag som skött det mesta här hemma så har det blivit värre nu, för han gör ingenting. Du vet, det var jag som städade, tvättade, manglade, handlade, lagade mat, putsade skor, lade fram rena kläder, ja allt. Ola jobbade mest, skötte bilen och huset. Så har det alltid varit. Men nu känns det som att jag får dra hela lasset själv utan att han gör någonting, förutom lagar saker när de går isönder och jobbar. Det har blivit annorlunda och snart orkar jag inte mer utan skiter i alltihopa. (Ingela, 39 år)

I båda materialen finns emellertid också exempel på par med en till synes god känslomässig relation, där kvinnan trots allt är kritisk mot mannens agerande på vissa områden. En av de engelska kvinnorna upplevde t.ex. att hennes man hade en i många avseende felaktig bild av föräldraskapet då han agerade som om detta endast innebar:»... going to work, coming home, going to the park, pushing a pram around the park, kicking football or having picnics. The baby would sleep right through the night "(Irene, 32 år). På ett liknande sätt kritiserar en av de svenska kvinnorna mannens engagemang i hemmet och barnen: 
Det har tagit tid för min man att hitta sin papparoll. Jag kan inte riktigt sätta fingret på varför det varit så men jag har alltid tagit hand om barnen och han har på något sätt hamnat lite vid sidan av. $\mathrm{Nu}$, de sista åren, har han trots allt börjat ta ett större ansvar men fortfarande är det så, att om inte jag talar om för honom vad han skall göra så vet han inte det. Han kan t.ex. komma hem efter jobbet och gå och lägga sig i soffan utan att fråga barnen hur de haft det eller om de har läxor. Han jobbar i och för sig mycket men så gör man ändå inte... När jag inte är hemma får barnen mest ta ansvar för sig själva, tror jag. Han och barnen har i och för sig mycket tillsammans med fotbollen där han är tränare för laget och sitter med i styrelsen. Det är träning, match eller möten nästan varje dag i veckan och de åker ofta på träningsläger. Det får han helt sköta själv tillsammans med dom. (Mia, 41 år)

Mias berättelse är ett tydligt exempel på hur mannens engagemang inte överensstämmer med kvinnans förväntningar. Samtidigt genererar den också frågan om det inte helt enkelt finns en kvinnlig norm för faderskapet. Citatet kan nämligen ses i relation till Palkovitzs (1996) diskussioner om att män har olika uttryck för sitt engagemang i faderskapet. Han är kritisk till att engagemanget alltför ofta beskrivs utifrån ett mycket litet antal variabler som rör hushållsarbetet eller praktiska bestyr med barnen. Istället menar han att man även bör inkludera andra värden, som förmår beskriva fädernas hela känslomässiga engagemang $i$ hemmet eller barnen. Detta behöver alltså, enligt Palkovitz, inte ta sig uttryck i direkta praktiska göromål utan kan istället yttra sig $\mathrm{i}$ att man t.ex. planerar för barnets framtid, oroar sig, värnar om barnet, alltid tänker på det eller, som i fallet ovan, att man aktivt engagerar sig i barnens fritidsintressen. Mias bild av faderskapet är kluven i detta avseende. Å ena sidan hävdar hon att hon "alltid tagit allt med barnen" och att han brister i omvårdnaden om dem, å andra sidan säger hon att han sköter allt med fotbollen vilket är »nästan varje dag i veckan".

I stora drag har således vårt material givit en betydligt mer komplex och mångfacetterad bild av mäns tankar och handlingar i familjelivets vardag än vad som återfinns $i$ mycket av den tidigare forskningen på detta område. Framför allt illustrerar våra resultat betydelsen av emotionella faktorer. När den känslomässiga relationen mellan parterna hotas eller bryter ihop, försvinner en viktig grundbult för upplevelsen av en rättvis arbetsfördelning i familjen. Denna iakttagelse stämmer väl med vissa andra forskares resultat. Lupton \& Barclay (1997) konstaterar t.ex. i sin litteraturgenomgång att kvinnor i de flesta undersökningar inte uttalar någon starkare kritik mot sina mäns intresse för hushållsarbetet eller barnen. Istället tycks de värdera naffective support, intima$\mathrm{cy}$, romantic love and companionate marriage« framför en »objektivt rättvis« fördelning av hushållsarbetet (op.cit., s. 56). Coltrane (1996) hävdar att oavsett vilka indikatorer man använder för att bestämma fördelningen av hushållsarbetet, så går det aldrig att exakt förutsäga hur det kommer att se ut $\mathrm{i}$ den enskilda familjen »because a mulitude of personal and social factors shape economies of gratitude and influence countless subtle negotiations over who does whatu. Vidare skriver han:

Couples do consider effiency and sometimes trade one form of labour for another, but often they divide household labour inefficiently 
and without regard to how much labour the spouse is performing. Couples also appear to divide housework in response to underlying power relations, but many refrain from using superior resources to avoid unpleasant tasks. Couple also regulary conform to gender stereotypes and espouse traditional attitudes, but sometimes ideology and practice do not coincide, and sometimes beliefs appear to be afterthe-fact justifications for practices that couples have already adopted (op.cit., s. 174).

Flera av resultaten $\mathrm{i}$ vår studie går $\mathrm{i}$ linje med det resonemang som Coltrane här för om bristen på samstämmighet mellan ideologi och praktik. Tydligast är det kanske i fallet med de engelska män som både gör mer i hemmet och ser sig själva som modernare i jämförelse med sina egna fäder, samtidigt som de ger uttryck för att vilja bibehålla de traditionella könsrelationerna inom familjen. Ett liknande exempel finner vi hos de män som hävdar att de har en mer progressiv syn på könsrelationerna än vad de omsätter i praktiken.

Om vi knyter detta till Connells resonemang om medlöperi (complicity) framträder en intressant bild. På ett allmänt plan konstaterar Connell att även om majoriteten av männen drar nytta av kvinnors underordning i samhället, är det ganska få som utövar en distinkt och entydig hegemonisk makt i förhållande till kvinnor. Om man, som vi har gjort här, studerar vardagliga relationer mellan män och kvinnor framträder de facto en ganska komplex bild. På en nivå, dvs. i sättet att tala om faderskapet, tycks de engelska fäderna fortfarande befinna sig nära den hegemoniska positionen. Samtidigt tycks de på en annan nivå, dvs. i praktiken, röra sig mot en position av demokratisk delaktighet.
När det gäller de svenska männen syns ett något annat, delvis motsatt mönster. I talet om faderskapet uttrycker nästan alla en tydlig strävan mot demokratisk delaktighet, samtidigt som en del fortfarande i praktiken uppvisar ett traditionellt beteende. Männen befinner sig alltså på olika positioner längs ett kontinuum mellan hegemonisk maskulinitet och demokratisk delaktighet, både i tal och handling.

\section{Sammanfattning}

Vid en närmare granskning av interaktionen mellan mäns föräldraskap och den allmänna faderskapsdiskursen i Sverige och England, finner man ett flertal intressanta likheter och skillnader. Ett tydligt resultat från vår studie är att den moderna diskursen kring faderskapet är mer etablerad i Sverige än i England, på alla nivåer i samhället. Detta har gjort det betydligt lättare för de svenska männen, att både i tanke och handling, integrera de nya förväntningarna på faderskapet med den egna synen på sig själva som män. I England däremot, har diskursen endast haft begränsad genomslagskraft på den individuella och sociokulturella nivån, vilket ibland ger männens tankar och handlingar en motsägelsefull inramning. Å ena sidan är det t.ex. inte längre möjligt för dagens män i England att upprepa sina egna fäders traditionella mansbeteende utan att möta motstånd från framför allt sin partner. Å andra sidan ger många av de engelska männen $i$ vår studie uttryck för en vilja att bibehålla de traditionella könsrollsmönstren. Detta tal om bestämda könsroller var däremot något mycket ovanligt hos de svenska männen, förmodligen eftersom det inte ryms inom 
ramen för de dominerande normativa föreställningarna om ett modernt faderskap.

Förutom att den moderna faderskapsdiskursen inte är lika etablerad i England som i Sverige, är den också på ett tydligt sätt mer klassmässigt skiktad. De engelska medelklassmännen är mest lika de svenska männen vad gäller benägenheten att både uttrycka sig och handla i linje med de nya förväntningarna. För arbetarklassmännen är situationen mer komplicerad. Samtidigt som dessa män är medvetna om de nya förväntningarna på faderskapet, motarbetas de ofta i sina försök att förändra sin situation, antingen av sin nära omgivning eller på grund av en alltför ekonomiskt instabil livssituation.

I Connells termer kan man på goda grunder hävda att den svenska diskursen om det nya och aktiva faderskapet blivit hegemonisk, eftersom det egentligen inte längre är accepterat att uttrycka några alternativa ståndpunkter, åtminstone inte i det offentliga samtalet. I detta perspektiv har den svenska familjepolitikens normativa grundkoncept haft stor genomslagskraft på i stort sett alla nivåer i samhället. Männen ökar successivt sitt ansvarstagande för barnen och deltar i allt större utsträckning i det traditionella hushållsarbetet, dvs. de blir allt mer familjeorienterade (Björnberg, 1994). Samtidigt visar vårt material att faderskapet också påverkas mycket starkt av de strukturella arrangemangen som utgör ett av fundamenten för denna politik. Svenska par hänvisar ofta till ekonomiska överväganden när de talar om fördelningen av familjearbetet. Att ekonomin tycks ha en så central betydelse för de svenska parens förhandlingar skall ses mot bakgrund av det se- naste decenniets kris i de svenska finanserna. Åtstramningspaketen har avlöst varanda och försöken att sanera den statliga ekonomin har framför all drabbat barnfamiljerna (Nelander \& Lindgren, 1997). Minskade subventioner, neddragningar i socialförsäkringssystemet, ökad arbetslöshet och en växande oro för anställningstryggheten ligger alltså bakom parens starka fokusering på ekonomin. Trots att Sverige idag besitter ett av världens mest generösa socialförsäkringssystem har således andra faktorer, som ligger utanför själva systemet, inverkan på hur paren utnyttjar de givna möjligheterna. Parens argumentation för den ofta traditionella fördelningen av föräldraledigheten speglar detta på ett tydligt sätt. Detta har givit resultatet att svenska män tar ut 10,4 procent (ca 44 dagar) av det totala antalet möjliga dagar till föräldraledighet (RFV, 1998). Siffrorna framstår som försvinnande små i proportion till kvinnornas utnyttjande av föräldraledigheten. Men i relation till situationen i England får de en delvis annan innebörd. Engelska män erbjuds överhuvudtaget inga möjligheter till betald föräldraledighet. Sammanfattningsvis visar vår studie att situationen i Englad är både mer komplex och svårtolkad än i Sverige. Ett intressant och kanske överraskande resultat är t.ex. att flera av de arbetslösa engelska männen uppvisade ett förhållandevis aktivt engagemang $\mathrm{i}$ hemmet och barnen. I många fall var dessa män huvudansvariga för arbetet $\mathrm{i}$ hemmet medan kvinnorna var på arbetet utanför hemmet.

I stora drag framgår det, framför allt av det svenska materialet, att möjligheten att utveckla ett mer omsorgsgivande och jämställt föräldraskap för män är beroende av 
tydliga normer och en stödjande familjepolitik. Detta är dock ingen garanti för att enskilda mäns agerande förändras. Individuella bevekelsegrunder och relationen till partnern har ofta en helt avgörande betydelse för utfallet, både i negativ och positiv riktning. Det visar sig inte minst i det engelska materialet, där vissa män trots klart sämre strukturella förutsättningar hade funnit nya vägar till ett förändrat faderskap. Så, även om män i både Sverige och England fortfarande drar fördelar av den patriarka- liska strukturen i samhället, motsäger resultaten från vår studie påståendet från tidigare forskning, att det aktiva och omsorgsgivande faderskapet endast är en ny form av hegemonisk maskulinitet. Snarare vill vi göra gällande att männen, inom ramen för det patriarkaliska systemet, har börjat förändras mot ett större engagemang i familjelivet. Processen är dock beroende av understöd i form av strukturella förändringar och konstruktiva socialpolitiska initiativ.

\section{Summary Men's parenthood On fatherhood and masculinity in Sweden and England}

This article outlines some of the findings of a comparative research project carried out in Sweden and Britain which examined the influence of fatherhood on men's understanding and experience of their masculinity.

The paper draws on empirical material from interviews with men and their partners in both countries to explore how fatherhood formation takes place as an ongoing process within intimate relationships and also in the context of wider structural factors. The research illustrates the influence of the contemporary discourse of the "involve" father in both countries and shows that the ways in which this affects men's practices is dependent on a wide range of factors including economic circumstances, social policies, political history and the emotional relationship between partners. In particular, the influence of class is of particular significance in the British context, while it is less of a factor in Sweden.

It is argued that, although the process is uneven, men's practices as fathers are shifting towards more involvement in childcare and houshold labour and that this process can be assisted by structural changes and social policy initiatives. 


\section{Litteratur}

Backett, K. (1987) "The negotiation of fatherhood" ur Lewis \& O'Brien (red) Reassessing Fatherhood-New observations on fathers and the modern family, London: SAGE.

Berk, S.F. (1985) The Gender Factory: the apportionment of work in American households, New York: Plenum.

Björnberg, U. (1994) »Mäns familjeorientering i förändring» ur Björnberg U. mf.l Janus och genus, Stockholm: Brombergs.

Brandht, B. \& Kvande, E. (1998) „Masculinity and child care: the reconstruction of fathering.", The Sociological Review, Vol 46. No 2.

Bäck-Wiklund, M. \& Bergsten, B. (1997) Det moderna föräldraskapet, Stockholm: Natur och Kultur.

Coltrane, S. (1996) Family Man: fatherhood, housework and gender equity, Oxford: Oxford University press.

Connell, R. W. (1995) Masculinities, London: Polity press.

Doucet, A. (1995) "Gender equality and gender differences in householdwork and parenting" Women's Studies International Forum, Årg. 18, $\mathrm{Nr} 3$.

Dryden, C. (1999) Beeing Married, Doing Gender, London: Routledge.

ESO (1996) Samhällets stöd till barnfamiljerna $i$ Europa. Finansdepartementet, Ds 1996:49.

Ferri, E. \& Smith, K. (1996) Parenting in the 1990s, London: Family Policy Studies Center.

Haas, L. (1993) „Nurturing fathers and working mothers: changing gender roles in Sweden" ur Hood, J.C. (red) Men, work and the family, London: SAGE.

Hantrais, L. \& Mangen, S. (1996) Cross-national research methods in the social sciences, London: Pinter.

Hearn, J. (1996) "Is masculinity dead? A critique of the concept of masculinity/masculinities", Mac an Ghaill, M. (red). Understanding Masculinities, Philadelphia: Open university Press.
Hochschild, A. (1989) The Second Shift: working parents and the revolution at home, New York: Viking Penguin.

Jalmert, L (1984) Den Svenske mannnen, Stockholm: Tidens Förlag.

Lewis, C. \& O'Brien, M. (red) (1987) Reassessing Fatherhood-New observations on fathers and the modern family, London: SAGE.

Lupton, D. \& Barclay, L. (1997) Constructing Fatherhood - discourses and experiences, London: SAGE.

Marsiglio, W. (red) (1995) Fatherhood - Contemporary theory, research and social policy, London: SAGE.

Nelander, S. \& Lindgren, V. (1997) Inkomstfördelning och inkomstutveckling - Vinnare och förlorare, Stockholm: LO-utredning.

O'Brien, M. (1992) "Changing conceptions of fatherhood" ur Björnberg, U. (red) European Parents in the 1990s: Contradictions and comparisons, London: Transaction Publishers.

Palkovitz, R. (1997) „Reconstructing involvement: Expanding conceptualizations of men's caring in contemporary families" ur Hawkins \& Dollahite (red) Generative Fathering - Beyond deficit models, London: SAGE.

RFV (1998) Statistisk information om uttaget i föräldraförsäkringen. www.rfv.se

Sandqvist, K. (1992)Pappor och riktiga karlar. Om mans- och fadersroller i ideologi och verklighet, Stockholm: Carlsson förlag.

Segal, L. (1990) Slow Motion: Changing masculinities, changing men, London: Virago.

SOU (1998) Ty makten är din... Myten om det rationella arbetslivet och det jämställda Sverige. Slutbetänkande från Kvinnomaktutredningen. 1998:6.

West, C. \& Zimmerman, D.H. (1987) „Doing gender". Gender and Society, Vol.1, No 2.

Wheelock, J. (1990) Husbands at Home: the domestic economy in a post-industrial society, London: Routledge. 